\title{
RAPID DETECTION OF THE AFRICANIZED HONEY BEE: A TOOL FOR INDONESIAN ANIMAL QUARANTINE
}

\author{
RIKA RAFFIUDIN ${ }^{\left(1^{*}\right.}$, ANIFA BINTAR ${ }^{(1}$, M. CHANDRA WIDJAJA ${ }^{(2}$, AHMAD \\ FARAJALLAH $^{(1}$, BAMBANG PURWANTARA ${ }^{(3)}$ \\ ${ }^{1}$ Department of Biology, Faculty of Mathematics and Natural Sciences, \\ Bogor Agricultural University, Bogor, Indonesia \\ ${ }^{2}$ Perhutani-West Java and Banten Province, Bandung, Indonesia \\ ${ }^{3}$ Department of Reproduction and Obstetrics, Faculty of Veterinary Medicine, \\ Bogor Agricultural University, Bogor, Indonesia
}

\begin{abstract}
Molecular detection methods were used to determine if Africanized Honey Bees (AHBs) are present in populations of imported Apis mellifera in Indonesia. The cytochrome $\mathrm{b}$ (cyt b gene) was amplified from mitochondrial DNA and digested with the $B g l \mathrm{II}$ restriction enzyme (cytb/BglII). Two types of animal DNA extraction kits were used and found suitable for rapid preparation of DNA from A. mellifera by the Animal Quarantine facility. Results showed that all 94 colony samples from beekeepers in Java produced a 485 bp PCR product from the amplification of this gene. Two DNA fragments of 194 and 291 bp from all samples were produced after digestion with $B g l \mathrm{II}$. This $c y t \mathrm{~b} / B g / \mathrm{II}$ result together with the DNA sequence of $c y t$ $\mathrm{b}$ showed that all collected samples of $A$. mellifera were the non-AHB type. Hence, this study did not detect AHB in Indonesia.
\end{abstract}

Key words : Apis mellifera, molecular detection methods, DNA, cytochrome b, mitochondrial genetics

\section{INTRODUCTION}

Apis mellifera currently found in Australia, America, and Asia (included Indonesia) are imported from Europe, Africa and the Middle East (Ruttner 1988). The most favorable for beekeepers is the A. mellifera ligustica subspecies due to its tame behaviour and high honey production.

Besides A. m. ligustica, an aggressive African honey bee subspecies, namely Apis m. scutellata was imported to Brazil in the mid-1950s. Since the introduction of this African subspecies into Brazil, descendent of 'Africanized' honey bees (AHB) have spread throughout the Neotropics and into temperate North America (Schiff and

${ }^{*}$ Corresponding author: rika_r@cbn.net.id 
Sheppard 1993). It inbred with the European Honey Bee $(\mathrm{EHB}=A . m$. ligustica or $A$. m. mellifera) became a killer AHB characterized as having a deadly sting (Castro et al. 1994), a high wing beat frequency (Spangler 1994), sensitivity to Varrhoa parasitic mites (Guerra et al. 2000), and rapid colony multiplication. Schiff and Sheppard (1993) have surveyed 422 feral honey bee colonies from non-Africanized areas in the southern United States and it revealed that over $21 \%$ of them had mitochondrial DNA (mtDNA) derived from a European race established in North America in the 17 th century, $77 \%$ of them had mtDNA common in honey bees maintained by beekeepers and about $1 \%$ exhibited African mtDNA. Further analysis revealed that the African mtDNA was derived from a North African subspecies imported to the US in the 19 th century.

The AHB can be distinguished from the non-AHB bees based on the mitochondrial cytochrome $\mathrm{b}($ cyt $\mathrm{b})$ gene digested with $B g l \mathrm{II}$ ( $c y t \mathrm{~b} / B g l \mathrm{II})$. The AHB cyt $\mathrm{b}$ does not have a restriction site for $B g l \mathrm{II}$, while the non-AHB has one $B g / \mathrm{II}$ restriction site. Therefore, the AHB type produces a single band of $495 \mathrm{bp}$, whereas the non-AHB PCR product produces a double band of 194 and 291 base pairs (bp) (Crozier et al. 1991). This method has been used by Australian bee keepers to detect the AHB imported to Australia. In the United States, cyt b has also been reported to detect the AHB (Pinto et al. 2003). However, currently the Indonesian Animal Quarantine Facility does not use a molecular detection method to recognize this AHB alien species. Hence, the aim of this study was to establish a rapid molecular detection method for detecting AHB status in Indonesia based on the $c y t \mathrm{~b} / B g l \mathrm{II}$. We used two DNA extraction kits designed for animal tissue for rapid DNA preparation from samples. This technique is appropriate for Animal Quarantine Officers to make a rapid and accurate decision on the presence of the AHB in imported colonies in Indonesia.

\section{MATERIALS AND METHODS}

\section{Apis mellifera Collection}

Imported A. mellifera were collected from apiaries located in Central Java (Pati, Kudus, Jepara) and in East Java (Jember, Malang, Kediri, Pasuruan), Indonesia. Bees were anesthetized and preserved in absolute ethanol.

\section{DNA extraction}

Genomic DNA was extracted from the thorax of single bee using phenolchloroform extraction and ethanol precipitation. In addition, we tested the Genomic DNA Mini Kit from Real Biotech Corporation (RBC) and the Genclean Column Genomic DNA Isolation Kit (GeneRay Biotech). For both kits, $20 \mathrm{mg}$ of bee thorax was used for DNA extraction, and single thorax in a $1.5 \mathrm{ml}$ microtube was immersed in liquid nitrogen for 15 min prior to being crushed using a grinder. Thereafter, the protocol according to the kit manufacturer was followed.

\section{A. mellifera DNA Amplification.}

Part of the cyt b region was amplified using primers of Cytochrome b Forward: 5'-tatgtactacctttgaggacaaatatc-3' (11400); Cytochrome b Reverse 5'- 
attacacctcctaatttattaaggaat-3' (11859) (Crozier et al. 1991). Numbers in brackets indicate the position of $A$. mellifera $c y t \mathrm{~b}$ in the complete mtDNA (Accession number L06178). Cycle sequencing conditions protocol was $2 \mathrm{~min}$. at $94^{\circ} \mathrm{C}$ for initial denaturing, 35 cycles of $30 \mathrm{~s}$ at $94^{\circ} \mathrm{C}, 30 \mathrm{~s}$ at $55^{\circ} \mathrm{C}$ and $1 \mathrm{~min}$. at $72{ }^{\circ} \mathrm{C}$ for DNA elongation, followed by $10 \mathrm{~min}$. for the DNA extension. DNA sequencing followed the ABI BigDye automated sequencing instruction from the supplier by using the same primers of as for DNA amplication.

\section{DNA Restriction Analysis}

Apis mellifera cyt b PCR products were digested using BglII restriction enzyme. The digestion mixture contained the cyt b PCR product, dd $\mathrm{H}_{2} \mathrm{O}$, Buffer D, BglII restriction enzyme and were incubated at $37^{\circ} \mathrm{C}$ overnight.

\section{DNA Alignment}

We used CLUSTALX (Thompson et al. 1997) program to align the DNA sequence generated in this study with the published AHB haplotypes provided in Genbank database (http://www.ncbi.nlm.nih.gov; Accession Number EF016646 and EF016647).

\section{RESULTS AND DISCUSSIONS}

\section{Apis mellifera cyt b Amplification and DNA Restriction Analysis}

We collected samples from 94 colonies of imported $A$. mellifera from big and small apiaries in Central and East Java (data not shown). All samples from the 94 colonies produced the same size DNA band approximately 500 bp ( Figure 1). PCR products from 94 samples were digested with $B g / I I$ and all produced two bands of approximately 200 and 300 bp (Figure 2).

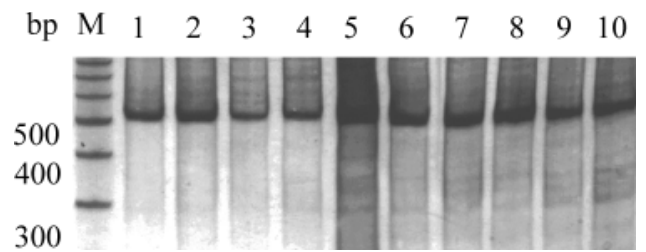

Figure 1. Cyt b PCR products from imported A. mellifera in Java, Indonesia; $\mathrm{M}=100$ bp DNA marker, $1-10=$ A. mellifera colony sample number 1-10 from Java, Indonesia 


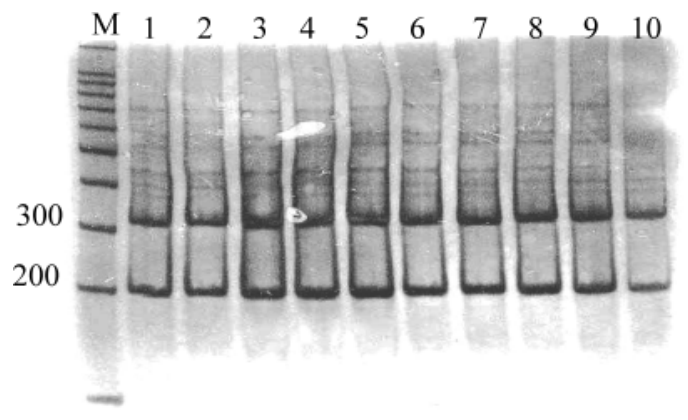

Figure 2 Cyt b/BglII restriction fragments of imported $A$. mellifera in Java, Indonesia; $\mathrm{M}=100 \mathrm{bp}$ DNA marker, $1-10=A$. mellifera colony sample number 1-10 from Java.

\section{Apis mellifera cyt $\mathrm{b}$ sequence data and alignment with AHB haplotypes}

Since all cyt $\mathrm{b}$ PCR product of Apis mellifera gave the same result (Figure 1 and 2), we only sequenced one bee, i.e. A. mellifera from colony number 9 from Pati, Central Java (Am9PT). PCR product of Am9PT cyt b sequence gave a total length of 485 bp (Figure 3). The BglII sites (sequence agatct) digested the PCR product into two fragments of 194 and 291 bp (Figure 3).

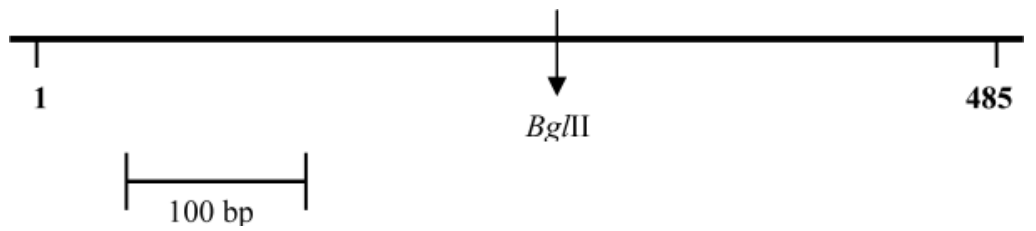

Figure 3. Restriction map of A. mellifera (Am9PT) cyt b/BglII. resulted for two DNA fragments of 194 and $291 \mathrm{bp}$

These results were in agreement with the data of Crozier (1991) from A. mellifera imported to Australia and data from the United States (Pinto et al. 2003) which have indicated that $c y t \mathrm{~b}$ can be used to detect the AHB. A total of 451 colonies have been screened for the AHB characters in the USA. The United States Department of Agriculture, Animal and Plant Health Inspection Service, Plant Protection and Quarantine used trap lines and morphological identification techniques. Based on morphology, the AHB and EHB could not be distinguished by beekeepers (Montesinos 1995). Hence, this accurate molecular technique can help solve the problem of detecting the AHB. Africanized honey bees are one of the invasive alien species that are banned from entering all nations including Indonesia. Therefore, this effective system for warning about invasive alien species is needed, especially due to global trade.

\section{AHB and non-AHB cyt b Alignment}

The DNA sequence alignment showed that the Am9PT cyt b sequenced in this study was exactly the same as that of Genbank Accession L06178; Crozier \& Crozier 1993) denoted for $A$. mellifera ligustica (Figure 4). Hence, Am9PT from this 
research was confirmed to be non-AHB bees. The primer amplified the partial cyt $\mathrm{b}$ gene started at nucleotide 396 of the complete $c y t \mathrm{~b}$ gene sequence. The BglII site was located at nuclotide 694 based on whole sequence (Figure 4).

\begin{abstract}
CYTBL06178
Am9 PT

EF 016646

EF016647

СYTBL06178

Am9PT

EF 016646

EF016647

CYTBL06178

Am9PT

EF 016646

EF016647

ATTCTTTTAATATCAATAGCAGCTGCATTTATAGGATATGTACTACCATGAGGACAAATA 420

A

.

- 24

$* * * * * * * * * * * * * * * * * * * * * * * *$

TCATATTGAGGTGAACAGFTATTACTAATCTTTTATCAGCAATTCCTTATATTGGTGAT 480 TCATATTGAGGTGCAACAGPTATTACTAATCTTTTATCAGCAATTCCTTATATTGGTGAT 84 TCATATTGAGGTGCAACAGPCATTACTAATCTTTTATCAGCAATTCCTTATATTGGTGAT 84 TCATATTGAGGTGCAACAG TTATTACTAATCTTTTATCAGCAATTCCTTATATTGGTGAT 84

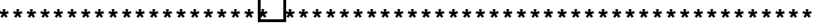

1

23

4

ACAATTGTATTATGAATTTGAGGTGATTTTCAATTAATAATGCTACATTAAATCGATTT 540 ACAATTGTATTATGAATTTGAGGTGGATTTTCAATTAATAATGCTACATTAAATCGATTT 144 ACAATTGTATTATGAATCTGAGGTGGTTCTCAATTAATAATGCTACCTTAAATCGATTT 144 ACAATTGTATTATGAATCTGAGGTGGGTTCTCAATTAATAATGCTACCTTAAATCGATTT 144 $* * * * * * * * * * * * * * * * * * * * * * * * * * * * * * * * * * * * * * * * * * * * * * * * * * * * * * * *$
\end{abstract}

CYTBL06178

Am9 PT

EF 016646

EF016647

CYTBL06178

Am9 PT

EF 016646

EF016647

CYTBL06178

Am9PT

EF 016646

EF016647

CYTBL06178

Am9 PT

EF 016646

EF016647

CYTBL06178

Am9PT

$\mathrm{EF} 016646$

EF016647_2

CYTBL06178

Am9PT

EF016646

EF016647

TTTTСTTTACATTTTATTTTACCATTATTAАTTTTATTTATAGTTATTCTTСATTTATTT 600

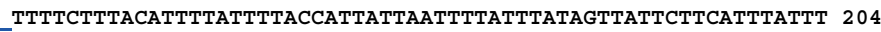
TTTTCTTTACATTTTATTTTACСATTATTAATTTTATTTATAGTTATTCTTCATTTATTT 204 TTTTCTTTACATTTTATTTTACCATTATTAATTTTATTTATAGTTATTCTTCATTTATTT 204

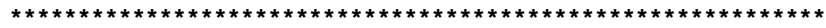

GCСTTACATTTAACTGGATCATCTAATCCTCTTGGATCAAATTTTAATAATTATAAAATT 660 GCCTTACATTTAACTGGATCATCTAATCCTCTTGGATCAAATTTTAATAATTATAAAATT 264 GCCTTACATTTAACTGGATCATCTAATCCTCTTGGATCAAATTTTAATAATTATAAAATT 264 GCCTTACATTTAACTGGATCATCTAATCCTCTTGGATCAAATTTTAATAATTATAAAATT 264

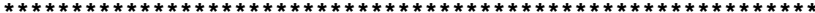

5.

6

TCATTTCATCCATATTTTCAATTAAAGA:T̈TTTTAGGATTTATATCATCTTATTTATC 720 TСATTTCATCСATATTTTTCAATTAAAGATGTTTAGGATTTTATATCATCTTATTTATC 324 TCATTTCATCCATATTTTTCAATTAAAGAंСGTTTAGGATTTTATATTATCTTATTTATC 324 TCATTTCATCCATATTTTTCAATTAAAGACGTTTTAGGATTTTATATTATCTTATTTATC 324 $\star * * * * * * * * * * * * * * * * * * * * * * * * * * * *) * * * * * * * * * * * * * * * * * * * * * * * * * * * *$

78

TTTATATTCATTAATTTTCAATTTCCATATCATTTAGGAGATCCAGACAATTTCAAAATT 780 TTTATATTCATTAATTTTCAATTTCCATATCATTTAGGAGATCCAGACAATTTCAAAATT 384 TTTATATTCATTAATTTTCAATTTCCATATCATTTAGGAGATCCAGATAATTTTAAAATT 384 TTTATATTCATTAATTTCAATTTCCATATCATTTAGGAGATCCAGATAATTTTAAAATT 384

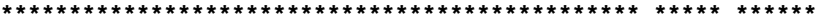

9

GCAAATCCAATAAATACTCCAACTCATATTAAACCTGAATGATATTTCCTATTTGCATAT 840 GCAAATCCAATAAATACTCCAACTCATATTAAACCTGAATGATATTTCCTATTTGCATAT 444 GCAAATCCAATAAATACTCCAACTCATATTAAACCTGAATGATATTTTCTATTTGCATAT 444 GCAAATCCAATAAATACTCCAACTCATATTAAACCTGAATGATATTTTCTATTTGCATAT 444

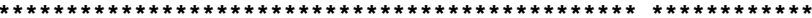

TCAATTTTACGAGCAATTCCTAATAAATAGGAGGTTAATCGGATTAGTAATATCAATT 900 TCAATTTTACGAGCAATTCCTAATAAATTAGGAGGTGTAATTCAATTTTACGAGCAATTCCTAATAAATTAGGAGGTGTAATTCAATTTTACGAGCAATTCCTAATAAATTAGGAGGTGTAAT$* * * * * * * * * * * * * * * * * * * * * * * * * * * * * * * * * * * * * * * * *$

Figure 4. A. mellifera Am9PT from this study aligned with Genbank $c y t b$ sequences CYTBL06178 (from A. m. ligustica Acc Num L06178), EF016646 (from AHB haplotype 1), and EF016647 (from AHB haplotype 2). ${ }^{*}=$ nucleotide homology. Underlined nucleotide $=$ BgIII sites. Solid boxed nucleotides $=$ nucleotide differences between AHB-1 and AHB-2. Dashed boxed nucleotides $=$ nucleotide change causing loss of BglII site in AHB type. Numbers positioned above the DNA alignment were all nucleotide differences between Am9 PT, and AHB haplotype 1 and haplotype 2 . 
DNA alignment between Am9PT and AHB haplotype 1 and AHB haplotype 2 from GenBank (Accession numbers EF016647 and EF016647, respectively) showed nine nucleotide differences (Figure 4, see the numbers above the nucleotide alignment). The difference between the AHB and the non-AHB at base number 295 was shown in Figure 4, labelled mutation number 5. This is the position of the restriction site for BglII; it could be observed that the nucleotide "T" in CYTBL06178 and Am9PT were altered to be a "C" in both AHB haplotypes 1 and 2 (EF016646 and EF016647). This mutation removed the $B g l \mathrm{II}$ restriction site, hence shows why a single band is seen in the AHB haplotypes. Based on homology analysis of the two AHBs, these two haplotypes also differ at nucleotide number 65 (Figure 4). The two AHB haplotypes obtained from Genbank were submitted on February 1, 2007 by Szalanski, A.L. and Mckern, J.A from the Department of Entomology, University of Arkansas, USA.

Based on the findings of this study, we suggest to carry out cooperation between the animal sections of the Agency of Agriculture Quarantine (Balai Karantina Pertanian) and the Apiaries Association in Indonesia. The cooperation could commence by performing a socialization of honey bee biology. Furthermore, the molecular detection for the AHB should be implemented at the animal quarantine in every province in Indonesia, particularly at Soekarno Hatta and Ngurah Rai airports, so that imported bees could be monitored.

\section{CONCLUSIONS}

Molecular analysis of imported $A$. mellifera based on the cytochrome $b$ gene from mitochondrial DNA digested with $B g l$ II restriction enzyme was conducted to determine whether the Africanized Honey Bee (AHB) is present in Indonesia. Out of 94 colony samples from 94 beekeepers in Java, all PCR products amplified from this gene were of the same size $(485 \mathrm{bp}$ ). Two DNA fragments (194 and 291 bp) were produced after digested with $B g l$ III. This $c y t$ b/BglII result showed that all collected samples of $A$. mellifera were of the non-AHB type. Hence, no AHB could be detected in Indonesia in this study. We found that two different DNA extraction kits could be successfully used to extract DNA for this analysis, allowing fast and effective preparation of DNA for subsequent PCR analysis.

\section{REFERENCES}

Castro F., Palma M., Brochettobraga M., Malaspina O., Lazaretti J., Baldo M., Antila M., Zuppi L., Croce J. and W. Cossermelli. 1994. Biochemical properties and study of antigenic cross-reactivity between Africanized Honey Bee and Wasp venom. Journal of Investigational Allergology \& Clinical Immunology, 4:37-41

Crozier R.H. 1977. Evolutionary genetics of the Hymenoptera. Annual Review of Entomology, 22:263-288

Crozier R.H. and Y.C. Crozier. 1993. The mitochondrial genome of the honeybee Apis mellifera: Complete sequences and genome organization. Genetics, 133:97-117

Crozier Y.C., Koulinous S. and R.H. Crozier. 1991. An improved test for Africanized honey bee mitochondrial DNA. Experientia, 47:968-969 
Guerra J. and L, D. DJ.Goncalves. 2000. Africanized honey bees (Apis mellifera L.) are more efficient at removing worker brood artificially infested with the parasitic mite Varroa jacobsoni Oudemans than are Italian bees or Italian/Africanized hybrids. Genetics \& Molecular Biology, 23:89-92

Montesinos P. 1995. Managing the Africanized honey bee. 2. American Bee Journal, 135:473-476

Perez-Castro E., May-Itza W. and J. Quezada-Euan. 2002. Thirty years after: a survey on the distribution and expansion of Africanized honey bees (Apis mellifera) in Peru. Journal of Apicultural Research, 41:69-73

Pinto M.A., Johnston J.S., Rubink W.L., Coulson R.N., Patton J.C. and W.S. Sheppard. 2003. Identification of Africanized Honey Bee (Hymenoptera: Apidae) Mitochondrial DNA;Validation of a Rapid Polymerase Chain Reaction-Based Assay. Annual Entomology Society of America, 96:679-684

Raffiudin R. 2002. Honey bee Behavioural Evolution and Itpr Gene Structure Studies. PhD. Thesis, James Cook University, Australia

Raffiudin R., Farajallah A., Purwantara B., Tjitrosoedirdjo S.S. and S. Tjitrosemito. 2006. Peranan Petugas Karantina terhadap Pengelolaan Hewan Asing Invasif dalam Kerangka SPS-WTO. In: Workshop Pengawasan Keamanan Hayati Hewani dan Sosialisasi Keamanan Hayati Hewani, Jakarta 21-23 November 2006

Ruttner F. 1988. Biogeography and Taxonomy of Honeybees. Springer-Verlag, Berlin

Ruttner F.L.T. and J. Louveaux. 1978. Biometrical-statistical analysis of the geographic variability of Apis mellifera L. Apidologie, 9:363-381

Schiff N. and W. Sheppard. 1993. Mitochondrial DNA evidence for the 19th century introduction of African honey bees into the United-States. Experientia, 49:530-532

Spangler H. 1994. Are the wingbeat frequencies of honey bees an indicator of population or behaviour. American Bee Journal, 134:53-55

Tegelstrom H. 1986. Mitochondrial DNA in natural population: an improved routine for screening of genetic variation based on sensitive silver staining. Electrophoresis, 7:226-229

Thompson J.D., Gibson T.J., Plewniak F., Jeanmougin F. and D.G. Higgins. 1997. The Clustal-X windows interface: flexible strategies for multiple sequence alignment aided by quality analysis tools. Nucleic Acid Research, 25:4876-4882. 
Thank you for evaluating AnyBizSoft PDF Splitter.

A watermark is added at the end of each output PDF file.

To remove the watermark, you need to purchase the software from

http://www.anypdftools.com/buy/buy-pdf-splitter.html 